Taylor; Hon. Secretary, F. H. C. Butler; Hon. Treasurer, H. W. Robinson; Council, Dr. H. P. Bayon, Prof. G. R. de Beer, C. N. Bromehead, J. G. Crowther, Dr. Dorothy Feyer, Dr. S. Lilley, Dr. D. McKie, H. T. Pledge, Dr. H. Shaw, Dr. H. Hamshaw Thomas, Sir Henry Thomas and Dr. E. Ashworth Underwood. The address of the honorary secretary is : Ravensmead, Keston, Kent.

\section{Colonial Medical Research Studentships}

ON the recommendation of the Colonial Medical Research Committee, the Secretary of State for the Colonies has instituted ten research studentships for graduates in medicine and cognate sciences, who desire by this means to prepare themselves for research work in tropical medicine and related subjects. The Studentships will carry an allowance at the rate of $£ 260$ per annum, and will normally be for a period of two years. They will be awarded on the advice of the Colonial Medical Research Committee, and will be tenable at any university or other appropriate institution as approved by the Committee. Candidates must be British subjects and graduates of British universities. Application should be made, through the head of the candidate's department, to the Secretary, Colonial Medical Research Committee, c/o Research Department, Colonial Office, London, S.W.1.

\section{Textile Institute}

The Textile Institute is offering a scholarship, under the terms of a grant from the Cotton Trade War Memorial Fund, to young craftsmen in the cotton spinning or weaving industry, and is planning an additional award for those who have not yet entered the industry. The scholarship will extend for not more than three years, and is of a maximum value of $£ 200$ prior to the final year, and $£ 350$ for the final year, during which it will provide the holder with practical experience abroad. Forms of application can be obtained from the General Secretary, Textile Institute, 16 St. Mary's Parsonage, Manchester 3 ; applications are to be made by July 1 .

Prof. Fred Bradbury, formerly head of the Department of Textile Industries at Belfast College of Technology, has been elected to honorary life membership of the Textile Institute. Prof. Bradbury took part in the formation of the Institute thirty-seven years ago, and was a member of the Institute's first Council elected in 1910.

\section{Congresses}

\section{International Congress on Short-Wave Therapeutics}

AN International Congress on Short-Wave Therapeutics will be held in Amsterdam during July 1924,1948 . Formal papers followed by discussions are being arranged. Particulars can be obtained from the Secretary of the Congress, Weteringschans 73, Amsterdam.

\section{International Congress on Engineering Education}

Prof. Richard Vieweg and Prof. Alwin Walther, with a small group of staff of the Darmstadt Technische Hochschule, are now trying to rebuild the college both as regards its buildings and its standing. They are accordingly organising, with the approval of the American Military Government, an International Congress on Engineering Education, to be held at Darmstadt during July 31-August 9. Feeding and housing of conference members from outside Germany will be undertaken by the American quartermaster's school at Darmstadt; suitable provision will also be made for Allied visitors from the other occupation zones. Darmstadt Technische Hochschule and the city of Darmstadt will furnish accommodation for Gevmans who attend. The preliminary programme indicates the following topics for discussion: (1) technology as an ethical and cultural opportunity; (2) present state and trends of development in engineering education throughout the world; (3) admission of students in relation to social problems; (4) exchange of professional ideas. Further information can be obtained from the Rector, Technische Hochschule Darmstadt, Kongressleitung, Darmstadt, U.S. Zone, Germany.

\section{Announcements}

Sir RoBert Robinson, Waynflete professor of chemistry in the University of Oxford and president of the Royal Society, has been awarded the Albert Medal of the Royal Society of Arts "for his outstanding contributions to the advancement of organic chemistry".

UNDER the Statute of the Royal Society which provides for the election of persons who either have rendered conspicuous service to the cause of science or are such that their election would be of signal benefit to the Society, Mr. Clement R. Attlee has been elected a fellow of the Society.

Dr. JoHN B. M. Coppock, head of the Technical Development Laboratories of the Fine Chemical Department, Boots Pure Drug Co., Ltd., Nottingham, has been appointed director of research of the recently formed British Baking Industries' Research Association.

Dr. F. N. Woodward has been lent to the Department of Scientific and Industrial Research for appointment as director of the United Kingdom Scientific Mission in the British Commonwealth Scientific Office in Washington. The present director, Dr. Alexander King, is shortly returning to the United Kingdom to take up an official appointment. Dr. Woodward is at present director of the Scottish Seaweed Research Association; during the War he was on the scientific staffs of the Ministries of Supply and Production. Dr. Woodward will also act as attache for scientific questions to the British Embassy in Washington.

The Council of the University of Sheffield has made the following appointments : G. L. Hermitte, to be lecturer in histology; F. T. Thorpe, to be lecturer in mental diseases; R. M. Haythornthwaite, to be lecturer in civil engineering.

Mr. J. G. Pearce, director of the British Cast Iron Research Association, writes to point out that in the article in Nature of May 10, p. 649, on the Birmingham conference of the Federation of British Industries, the last sentence of the remarks attributed to him may give rise to misunderstanding. The full text was: "Of the major functions of a research association, the creation of new knowledge by research, its application in a given case through development, and its dissemination by intelligence activities, the problems of development and dissemination have been least satisfactorily solved ..."

Erratum. In the communication "Nucleotide Metabolism of Bacteria and the Bacterial Nucleus" in Nature of April 26, p. 577, the illustration was inadvertently printed upside down. 